\title{
PENGARUH VARIASI TENDANGAN TERHADAP PENINGKATAN AKURASI TENDANGAN LINGKAR DALAM ATLET TARUNG DERAJAT KURATA II SATUAN LATIHAN KONI KOTA JAMBI
}

\author{
Oleh: Palmizal \\ (Universitas Jambi) \\ Email: Palmizal@unja.ac.id
}

\begin{abstract}
Abstrak
Akurasi tendangan lingkar dalam merupakan salaah satu bentuk tehnik yang harus dikuasai oleh atlet-atlet anggota Tarung Derajat agar pada saat melakukan tendangan lingkar dalamefektif dan tepat pada sasaran target. Penelitian ini merupakan penelitian kuantitatif dengan menggunakan metode eksperimen "Quasi Eksperimental" yang dilakukan dengan tujuan untuk mengetahui ada atau tidaknya pengaruh akibat perlakuan yang diberikan pada sampel yang diteli. Dimana penelitian ini menggunakan rancangan dengan satu kelompok melalui tes awal-tes akhir (one group pree test-post test) Instrumen pnelitian ini dimulai dari tes awal kemudian diberikan perlakuan latihan variasi tendangan sebanyak 16 kali pertemuan kemudian dinilai melalui tes akhir. Tim penilai adalah wasit juri yang bersertifikat nasional. Teknik pengambilan sampel adalah teknik purposive sampling, jadi populasi dijadikan sample dengan jumlah sampel 8 orang atlet. Hasil tes awal sebesar358 dengan rata-rata 44,75 sedangkan tes akhir adalah sebesar 382 dengan rat-rata 47,75. Hasil penelitian ini menunjukan bahwa $t_{\text {hitung }}>t_{\text {tabel }}$ maka artinya $t_{\text {hitung }}=3,865$ lebih besar dibandingkan dengan $t_{\text {tabel }}$ $=1,895$ dengan taraf kepercayaan 95\% maka $H_{0}$ ditolak dan $H_{a}$ diterima artinya :Terdapat Pengaruh Variasi Tendangan Terhadap Peningkatan Akurasi Tendangan Lingkar Dalam Atlet Kurata II Satuan Latihan KONI Kota Jambi. Maka dapat disimpulkan latihan variasi tendangan dapat berpengaruh terhadap Peningkatan Akurasi Tendangan Lingkar Dalam Atlet Kurata II Satuan Latihan KONI Kota Jambi.
\end{abstract}

Kata Kunci: Latihan variasi tendangan, Akurasi tendangan lingkar dalam

\section{THE EFFECT OF KICK VARIATION ON IMPROVING THE CIRCLE KICK ACCCURACY IN TARUNG DERAJAT OF KURATA II ATHLETE OF KONI JAMBI CITY EXERCISE UNIT}

\begin{abstract}
The accuracy of the circular kick is one of the technique mastered by members of the Tarung Derajat members in order to make the circumference kick is effective and right on target. This research is a quantitative study using Quasi Experimental which was conducted with the aim to study the presence or absence of participation given to the samples studied. This study uses research with the initial
\end{abstract}


Pengaruh Variasi Tendangan Terhadap Peningkatan Akurasi Tendangan Lingkar Dalam Atlet Tarung Derajat Kurata Ii Satuan Latihan Koni Kota Jambi

group test-final test (one group test before the post-test). This research instrument starts from the initial test and then given a training variation of kicks as many as 16 meetings then opened through the final test. The assessment team is a nationally certified referee. The sampling technique is a purposive sampling technique, so that a sample of 8 athletes is taken. Initial test results amounted to 358 with an average of 44.75 while the final test amounted to 382 with an average of 47.75 . The results of this study indicate that t_count $>t$ table means that t_count $=3.865$ is greater than t_tabel $=1.895$ with $95 \%$ confidence level, $H \_0$ is rejected and H_a is needed: There Is An Effect Of Kick Variations On Increasing The Accuracy Of Circular Kicks In Kurata II Athletes Exercise of KONI Jambi City Unit. So it can be concluded that kick variation training can affect the Accuracy of Circular Kick Accuracy in Kurata II of KONI Jambi City Unit.

Key Words: Kick variation training, Circular kick accuracy

Correspondence author: Palmizal, Universitas Jambi, Indonesia. E-Mail: Palmizal@unja.ac.id (c) (i) (2)

Jurnal HalamanOlahraga Nusantara licensed under a Creative Commons Attribution-ShareAlike 4.0 International License.

\section{A. PENDAHULUAN}

Olahraga merupakan aktivitas fisik maupun psikis seseorang yang berguna untuk menjaga dan meningkatkan kualitas kesehatan olahraga juga mempunyai peranan penting dalam upaya meningkatkan kualitas sumber daya manusia dan membentuk karakter, banyak cabang olahraga yang berkembang pesat di Indonesia, salah satunya beladiri. Olahraga beladiri merupakan cabang olahraga yang banyak diminati, cabang olah raga beladiri banyak berkembang dimasyarakat baik yang berasal dari dalam negeri maupun luar negeri, dari dalam negeri salahsatunya adalah tarung derajat, dalam beladiri tarung derajat banyak jenis pukulan dan tendangan diantaranya adalah tendangan lingkar dalam.

Tendangan lingkar dalam merupakan tendangan yang sangat efektif di dalam pertarungan karena berfungsi juga untuk drop atau menangkis serangan balasan dari lawan. Tendangan lingkar dalam adalah tendangan yang membentuk gerakan kaki melingkar ke arah dalam dengan lecutan dan ditarik kembali. Tendangan lingkar dalam yang baik yaitu dalam 
Pengaruh Variasi Tendangan Terhadap Peningkatan Akurasi Tendangan Lingkar Dalam Atlet Tarung Derajat Kurata Ii Satuan Latihan Koni Kota Jambi

menendang memiliki keseimbangan yang baik agar tidak goyang saat lawan menendang selain itu juga memiliki tiga unsur daya gerak dalam tarung derajat yaitu kekuatan, kecepatan, dan ketepatan. Untuk mendapatkan hasil tendangan lingkar dalam yang baik maka dibutuhkan bentuk latihan yang variatif, oleh sebab itu dalam latihan dilakukan dengan menggunakan metode variasi latihan tendangan yang bisa meningkatkan akurasi tendangan lingkar dalam. Dikarenakan akurasi tendangan lingkar dalam anggota tarung derajat Kota Jambi masih sangat rendah maka dibuatlah suatu metode latihan yang bias meningkatkan hasil tendangan lingkar dalam,

Peneliti mengamati saat melakukan tendangan lingkar dalam sulit untuk menjaga keseimbangan serta mengatur ketepatan maupun kecepatan tendangan pada target sasaran. Selain itu di dapati anggota tarung derajat yang tendanganya kurang tepat sasaran target dalam tendangan mengenai ped.

Tendangan lingkar dalam adalah tendangan lingkar yang membentuk gerakan kaki melingkar ke arah dalam dengan lecutan dan ditarik kembali. Dengan bentuk gerakan posisi kaki yang ingin menendang lutut dilipat kesamping dengan paha mengarah kedepan lebih tinggi dari pada selangkangan dan posisi badan agak condong kebelakang, ditendangkan ke arah depan dengan lebih tinggi dari pada pinggang dengan posisi tangan mengepal melindungi bagian rusuk dan rahang (Dradjat 2003).

Dalam (Trisno 2011)“Ketepatan tendangan lingkar dalam adalah: Tendangan dikatakan benar apabila tendangan lingkar dalam tersebut melewati pembatas sikut yang sejajar dengan bahu dan tepat pada target sasaran dengan tumpuan kaki yang seimbang.

Syarat-syarat tendangan:

1. Harus fleksibility.

2. Kaki tumpuan harus kokoh.

3. Bisa menjaga keseimbangan dengan baik. 
Dalam tendangan itu sendiri harus terdapat unsur-unsur tendangan sesuai pada 5 unsur daya gerak dalam olahraga tarung derajat yaitu kekuatan, kecepatan, ketepatan, keberania dan keuletan. Adapun unsur dalam tendangan yang harus dimiliki diantaranya yaitu kecepatan, ketepatan dan kekuatan atau power:

\section{B. METODE}

Penelitian judul ini dilaksanakan disatuan latihan tarung derajat KONI Kota Jambi

Rancangan Penelitian

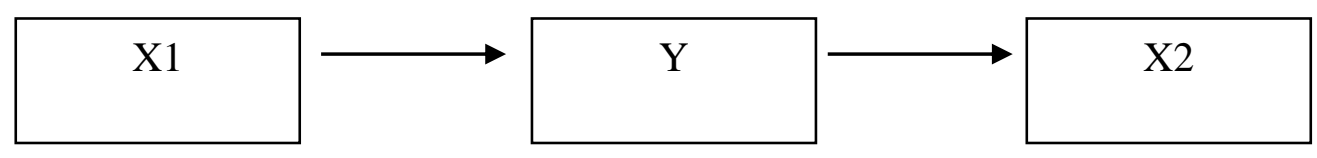

Keterangan:

$\mathrm{X} 1=$ Pre test (tes awal)

$\mathrm{Y}=$ Treatment (perlakuan)

$\mathrm{X} 2=$ Post test (tes akhir)

Populasi dalam penelitian ini adalah seluruh atlet tarung derajat kurata II di satuan latihan tarung derajat KONI Kota Jambi sebanyak 16 orang, dengan menggunakan teknik purposive sampling maka populasi dalam penelitian ini adalah 8 orang yang aktif mengikuti latihan.

Tehnik dalam pengumpulan data ini yaitu peneliti mengambil metode tes dan pengukuran yang mana dalam penelitian ini yang menjadi ukurannya yaitu melakukan tendangan lingkar dalam dengan metode latihan yang telah diberikan sebelumnya, langkah-langkah untuk mendapatkan data penelitian ini adalah sebagai berikut: persiapan alat dan kelengkapan yang digunakan dalam penelitian, tempat pelaksanaan penelitian, tenaga pembantu, tes awal, program latihan dan tes akhir. 
Pengaruh Variasi Tendangan Terhadap Peningkatan Akurasi Tendangan Lingkar Dalam Atlet Tarung Derajat Kurata Ii Satuan Latihan Koni Kota Jambi

Cara pengambilan data tes tendangan lingkar yaitu dengan melakukan tendangan sebanyak 30 kali menendang ke arah sasaran peddihitung berapa banyak tandangan yang dilakukan dengan unsur tendangan cepat, tepat dan berpowermengenai sasaran target dengan benar. Masing-masing sampel melakukan tes tendangan lingkar dalam sebanyak 30 kali tendangan dengan waktu 60 detik dan dihitung tendangan dengan unsur benar, kemudian dihitung kedalam formulir tes melalui test pertama yaitu pree test dan dilanjutkan dengan test kedua yaitu post test. Dalam penelitian

Untuk mendapatkan kategori penilaian dari tendangan lingkar pertama-tama dilakukan pree test yaitu melakukan tendangan lingkar dalam dalam sebanyak 30 kali tendangan dan dihitung berapa banyak tendangan yang mengenai sasaran atau target dalampencapain 30 kali tendangan lingkar dalambenar dan seimbang dengan klasifikasi lima kelas sehingga di dapatkan rentang. Adapun hasil dari pree test tendangan lingkar dalam sebagai berikut:

\begin{tabular}{ccc}
\hline No & Jumlah Tendangan & Kategori \\
\hline 1 & $>28$ & Sangat Baik \\
\hline 2 & $24-28$ & Baik \\
\hline 3 & $21-24$ & Cukup \\
\hline 4 & $17-21$ & Kurang \\
\hline 5 & $<17$ & Kurang Baik \\
\hline
\end{tabular}

Analisis data dilakukan untuk menguji hipotesis yang telah dirumuskan. Uji hipotesis yang dipergunakan adalah (T-Test). Sebelum melakukan (T-Test), terlebih dahulu populasi harus berdistribusi normal dan bervariansi homogen (Sudjana 2005)

\section{HASIL DAN PEMBAHASAN}

Tes awal pada penelitian ini menggunakan sasaran target yaitu ped, sehingga dalam tes awal ini tidak ada perlakuan pada siswa tersebut. Dalam 
Pengaruh Variasi Tendangan Terhadap Peningkatan Akurasi Tendangan Lingkar Dalam Atlet Tarung Derajat Kurata Ii Satuan Latihan Koni Kota Jambi

tes awal ini didapatkan jumlah nilai keseluruhan kemampuan akurasi tendagan lingkar dalam atlet kurata II satuan latihan KONI Kota Jambi adalah 358, dengan demikian dapat dirata-ratakan kemampuan akurasi tendagan lingkar dalam atlet kurata II satuan latihan KONI Kota Jambi adalah 44,75 .

Berdasarkan analisis data tes awal (pre test) kelompok latihan metode interval ekstensif dengan jumlah sampel 8 diperoleh skor tertinggi52 skor terendah 30, rata-rata (mean)44,75, median 46, modus 52, dan simpangan baku (SD) 9,99. untuk lebih jelasnya dapat dilihat pada tabel distribusi frekuensi di bawah ini:

Distribusi Frekuensi Pree Test Akurasi Tendangan Lingkar Dalam

\begin{tabular}{cccc}
\hline Kelas Interval & F1 & Fk & Fr \\
\hline $30-32$ & 1 & 1 & $12.5 \%$ \\
\hline $33-34$ & 0 & 0 & $0 \%$ \\
\hline $35-37$ & 0 & 0 & $0 \%$ \\
\hline $38-40$ & 1 & 2 & $12.5 \%$ \\
\hline $41-43$ & 1 & 3 & $\mathbf{2 5 \%}$ \\
\hline $48-47$ & 2 & 5 & $12.5 \%$ \\
\hline $51-53$ & 1 & 6 & $25 \%$ \\
\hline Jumlah & 2 & 8 & $100 \%$
\end{tabular}

Untuk lebih jelasnya dapat dilihat pada diagram batang di bawah ini:

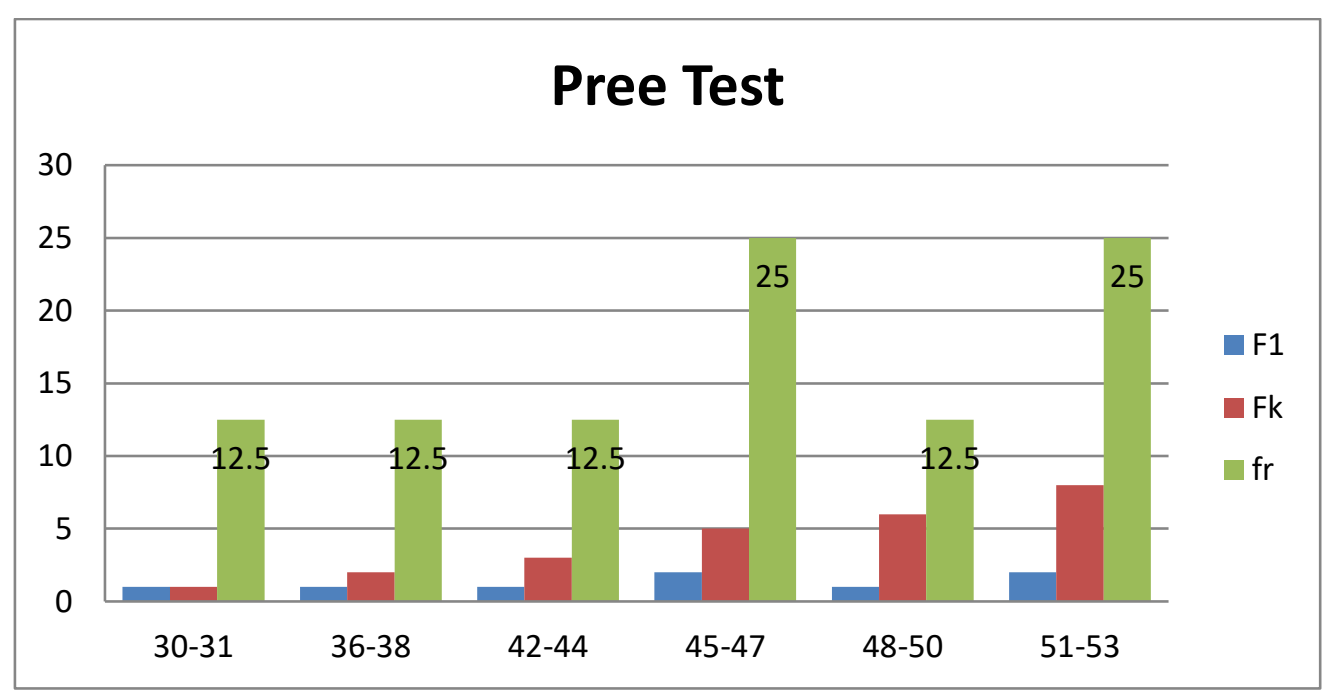

Diagram Batang Pree Test Akurasi tendangan lingkar dalam 
Pengaruh Variasi Tendangan Terhadap Peningkatan Akurasi Tendangan Lingkar Dalam Atlet Tarung Derajat Kurata Ii Satuan Latihan Koni Kota Jambi

\section{Tes Akhir Hasil Akurasi Tendangan Lingkar Dalam}

Tes akhir penelitian ini yaitu tes yang dilakukan setelah atlet tersebut diberi perlakuan, sehingga pada tes akhir ini merupakan tes setelah melakukan latihan variasi tendangan kepada akurasi tendagan lingkar dalam atlet kurata II satuan latihan KONI Kota Jambi tersebut selama 6 minggu. Pada tes akhir ini didapatkan jumlah kemampuan akurasi tendagan lingkar dalam atlet kurata II satuan latihan KONI Kota Jambi adalah dengan jumlah 382, dengan demikian rata-rata kemampuan akurasi tendagan lingkar dalam atlet kurata II satuan latihan KONI Kota Jambi adalah adalah sebesar 47,75.

Berdasarkan analisis data tes awal (pre test) kelompok latihan metode interval ekstensif dengan jumlah sampel 8 diperoleh skor tertinggi 54 skor terendah 36, rata-rata (mean)47,75, median 46, modus 48 dan 50, simpangan baku (SD) 5,59. untuk lebih jelasnya dapat dilihat pada tabel distribusi frekuensi di bawah ini:

Distribusi Frekuensi Post Test Akurasi Tendangan Lingkar Dalam:

\begin{tabular}{cccc}
\hline Kelas Interval & F1 & Fk & Fr \\
\hline $36-38$ & 1 & 1 & $12.5 \%$ \\
\hline $39-41$ & 0 & 0 & $0 \%$ \\
\hline $42-44$ & 1 & 2 & $12.5 \%$ \\
\hline $45-47$ & 0 & 0 & $0 \%$ \\
\hline $48-50$ & 4 & 6 & $\mathbf{5 0 \%}$ \\
\hline $51-52$ & 1 & 7 & $12.5 \%$ \\
\hline $53-55$ & 1 & 8 & $100 \%$ \\
\hline Jumlah & 8 & 24 &
\end{tabular}


Palmizal, (2020)

Pengaruh Variasi Tendangan Terhadap Peningkatan Akurasi Tendangan Lingkar Dalam Atlet Tarung Derajat Kurata Ii Satuan Latihan Koni Kota Jambi

Untuk lebih jelasnya dapat dilihat pada diagram batang di bawah ini:

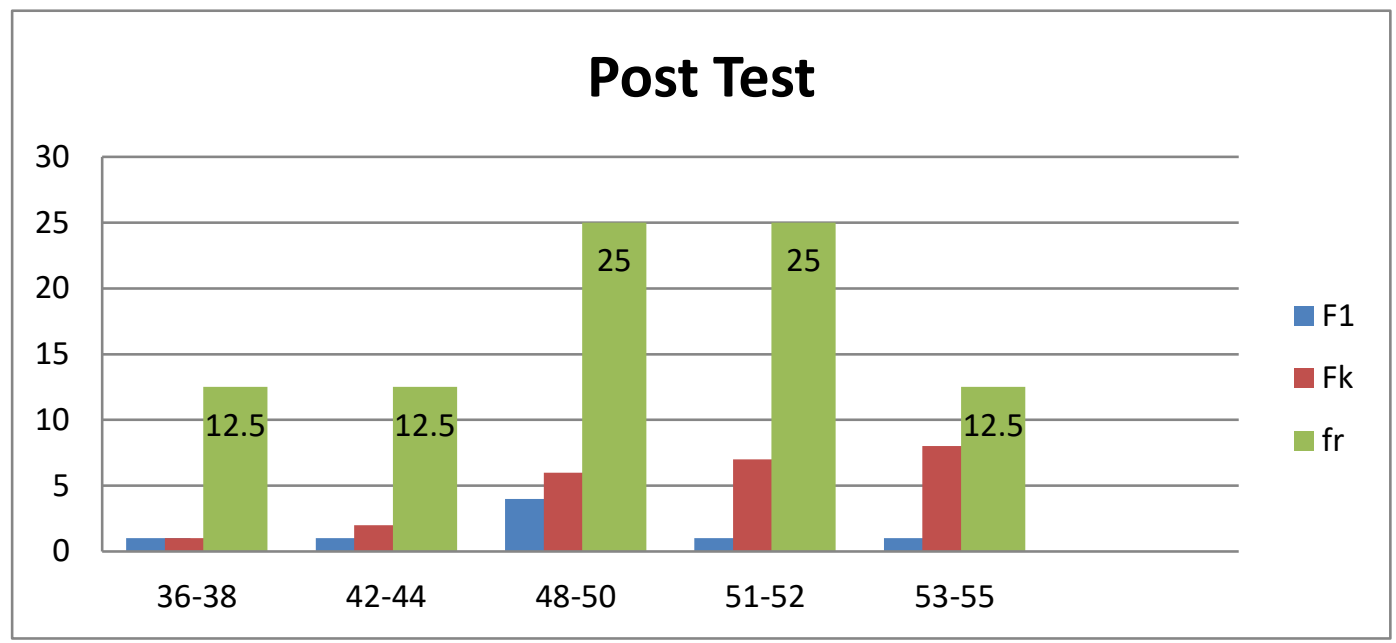

Diagram Batang Post Test Akurasi tendangan lingkar dalam

Perbandingan Hasil Tes Awal Dan Tes Akhir

Perbandingan Hasil Tes Awal Dan Tes Akhir

\begin{tabular}{ccc}
\hline Kelas Interval & Pree Test & Post Test \\
\hline $30-32$ & 1 & 0 \\
\hline $36-38$ & 1 & 1 \\
\hline $42-44$ & 1 & 1 \\
\hline $45-47$ & 2 & 0 \\
\hline $48-50$ & 1 & 1 \\
\hline $51-52$ & 2 & 1 \\
\hline $53-55$ & 0 &
\end{tabular}

Untuk lebih jelasnya dapat dilihat pada diagram batang di bawah ini:

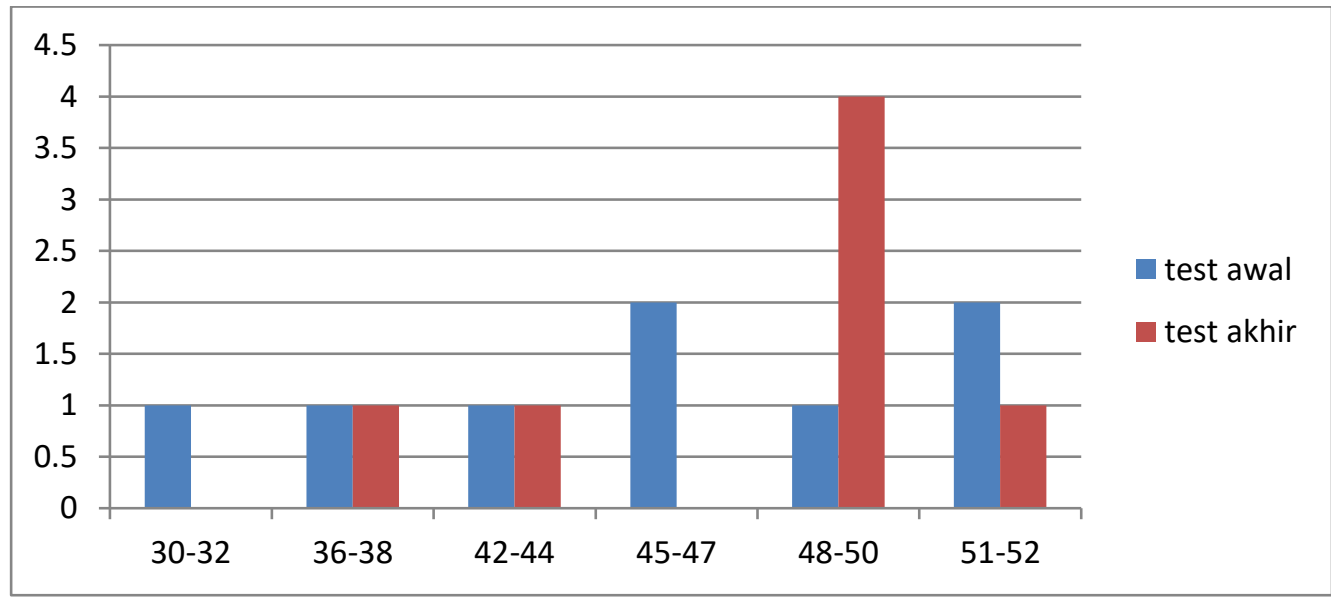


Pengaruh Variasi Tendangan Terhadap Peningkatan Akurasi Tendangan Lingkar Dalam Atlet Tarung Derajat Kurata Ii Satuan Latihan Koni Kota Jambi

Diagram Batang Pree Test dan Post Test Akurasi tendangan lingkar dalam Jika dilihat dari hasil kemampuan akurasi tendagan lingkar dalam atlet kurata II satuan latihan KONI Kota Jambi adalah pada tes awal sebesar 358 dibandingkan dengan hasil kemampuan akurasi tendagan lingkar dalam atlet kurata II satuan latihan KONI Kota Jambi adalah 382 terlihat tampak perbedaan diantara kedua hasil tersebut. Hal ini dapat dilakukan dengan

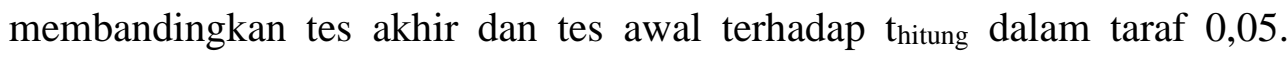
Apabila thitung lebih kecil dari $t_{\text {tabel }}$ ini berarti adanya perbedaan yang berarti dan sebaliknya apabila $t_{\text {hitung }}$ lebih besar dari $t_{\text {tabel }}$ ini berarti tidak adanya perbedaan yang berarti. Berikut ini adalah tabel hasil penelitian latihan variasi latihan tendangan terhadap peningkatan akurasi tendagan lingkar dalam atlet kurata II satuan latihan KONI Kota Jambi adalah Jambi sebagai berikut :

Hasil uji normalitas tesakurasi tendangan lingkar dalam

\begin{tabular}{cccccc}
\hline NO & Bentuk Tes & Sampel & Lhitung & Ltabel & Kerterangan \\
\hline 1 & Tes awal (Pretest) & 8 & 0,0596 & 0,285 & Normal \\
\hline 2 & Tes akhir (Postest) & 8 & 0,2307 & 0,285 & Normal \\
\hline
\end{tabular}

Hasil data tes awal $\mathrm{L}_{\text {hitung }} 0,0596<\mathrm{L}_{\text {tabel }} 0,285$ maka dikatakan normal, dan hasil data tes akhir $\mathrm{L}_{\text {hitung }} 0,2307<\mathrm{L}_{\text {tabel }} 0,285$ maka dikatakan normal.

Hasil Homogenitas tes akurasi tendangan lingkar dalam

\begin{tabular}{ccccccc}
\hline NO & Bentuk Tes & Sampel & S & F $_{\text {hitung }}$ & F tabel $_{n}$ & Kerterangan \\
\cline { 1 - 3 } 1 & Tes awal (Pretest) & 8 & 9,99 & \multirow{2}{*}{1,66} & 3,44 & Homogen \\
\cline { 1 - 4 } 2 & Tes akhir (Postest) & 8 & 5,59 & & & \\
\hline
\end{tabular}

Hasil data tes awal dan akhir $F_{\text {hitung }}$ 1,66 $<\mathrm{F}_{\text {tabel }}$ 3,44 maka dikatakan homogen.

Hasil Hipotesis Tendangan lingkar dalam

\begin{tabular}{ccccccc}
\hline NO & Bentuk Tes & Sampel & D & Thitung $_{\text {Tabel }}$ & T $_{\text {tarterangan }}$ \\
\hline 1 & Tes awal (Pretest) & 8 & \multirow{2}{*}{4,75} & 3,865 & 1,895 & $\begin{array}{c}\text { Diterima pada tingkat } \\
\text { kepercayaan } 95 \%\end{array}$ \\
\hline 2 & Tes akhir (Postest) & 8 & & & & \\
\hline
\end{tabular}


Pengaruh Variasi Tendangan Terhadap Peningkatan Akurasi Tendangan Lingkar Dalam Atlet Tarung Derajat Kurata Ii Satuan Latihan Koni Kota Jambi

Hasil data hipotesis $\mathrm{T}_{\text {hitung }} 3,865>\mathrm{T}_{\text {tabel }}$ 1,895 maka diterima pada tingkat kepercayaan $95 \%$.

Berdasarkan analisis data dan pengujian hipotesis yang menggunakan rumus uji t dalam penelitian ini, diharapkan dapat melahirkan kesimpulan yang tepat sesuai dengan data yang diperoleh. Adapun kesimpulan yang diperoleh mengacu dan tidak lari dari data yang diperoleh. Dengan demikian akan memperlihatkan gambaran langsung dari data yang didapatkan selama penelitian eksperimen dilakukan. Untuk itu perlu pengkajian tentang metodologi dan kajian teori dari penelitian. Pengetahuan yang diperoleh melalui pendekatan ilmiah dan dibuat berdasarkan teori-teori secara sistematis dan dilakukan dengan langkah-langkah atau prosedur yang benar, maka pengetahuan yang didapatkan tentu benar pula, dengan demikian hasil penelitian dapat diterima kebenarannya.

Berdasarkan hasil analisis dari tes awal sampai tes akhir diperoleh harga $t_{\text {hitung }}$ sebesar 3,865 bila dibandingkan dengan $t_{\text {tabel }}$ 1,895 ini menunjukkan terdapatnya peningkatan yang berarti. Hal ini disebabkan oleh pelaksanaan perlakuan dalam suatu latihan sebanyak 16 kali pertemuan dengan frekuensi 3 kali seminggu. Hal ini menunjukkan bahwa sudah jelas hasil yang diperoleh pada tes akhir dan tes awal, karena sampel telah diberi perlakuan maka semakin baik hasil yang diperoleh.

Dari analisis data yang dilakukan, ternyata hipotesis alternatif (Ha) yang dikemukakan dalam penelitian ini diterima kebenarannya dengan menunjukan tes awal dan tes akhir berbeda, dengan kata lain terjadi peningkatan antara tes awal dan tes akhir, dan dapat disimpulkan bahwa terdapat terdapat pengaruh dari latihan variasi tendangan ini atlet putra akurasi tendagan lingkar dalam atlet kurata II satuan latihan KONI Kota Jambi. 
Pengaruh Variasi Tendangan Terhadap Peningkatan Akurasi Tendangan Lingkar Dalam Atlet Tarung Derajat Kurata Ii Satuan Latihan Koni Kota Jambi

\section{KESIMPULAN}

Berdasarkan hasil dari analisis data, diketahui bahwa pengaruh latihanvariasi tendangan terhadap peningkatan kemampuan akurasi tendagan lingkar dalam atlet kurata II satuan latihan KONI Kota Jambi adalah 338 tes awal, dengan demikian dapat dirata-ratakan kemampuan akurasi tendagan lingkar dalam atlet kurata II satuan latihan KONI Kota Jambi adalah denagan rata-rata 44,75, dan tes akhir 382 dengan rata-rata 47,75, maka kesimpulan dari penelitian ini yaitu terdapat peningkatan yang signifikan latihan variasi tendanagan terdapat peningkatan kemampuan akurasi tendagan lingkar dalam atlet kurata II satuan latihan KONI Kota Jambi dengan rata-rata 47,72 pada tes akhir lebih baik dibandingkan dengan atlit yang tidak melakukan latihan variasi tendangan sama sekali. Kesimpulan didukung hasil uji normalitas yaitu hasil data tes awal $\mathrm{L}_{\text {hitung }} 0,0596<\mathrm{L}_{\text {tabel }}$ 0,285 maka dikatakan normal, dan hasil data tes akhir $\mathrm{L}_{\text {hitung }} 0,2307<\mathrm{L}_{\text {tabel }}$ 0,285 maka dikatakan normal. Didukung lagi dengan $F_{\text {hitung }}=1,66 \geq$ $F_{\text {tabel }}=3,44$ homogen. Dan uji-t yaitu $\mathrm{T}_{\text {hitung }}=3,865>\mathrm{T}_{\text {tabel }}=1,895$ hal ini berarti hipotesis penelitian diterima pada tingkat $95 \%$ signifikan.

\section{DAFTAR PUSTAKA}

Dradjat, Achmad Guru Haji. 2003. Kawah Dradjat Bandung: Pusat Pembinaan Moral Dan Mental (MORTAL-GHADA). Bahan dan Pelatihan Tarung Derajat Tingkat Pelatihan Pengda KODRAT se Indonesia.

Sudjana, Nana. 2005. “Metode Statistika.” Bandung: Tarsito 168.

Trisno, Ardiansyah. 2011. "Pengaruh Latihan Multi Balance Terhadap Ketepatan'Tendangan Lingkar' Dalam Atlet Tarung Derajat Kurata 2 Satuan Latihan UKM UNJA.” FIK UNJA. 